\title{
The relationship between eye-winking tics, frequent eye-blinking and blepharospasm
}

\author{
J S ELSTON, F CAS GRANJE, A J LEES \\ From the National Hospitals for Nervous Diseases, Queen Square, London, UK
}

SUMMARY A family is reported in which three generations were affected with eye-winking tics and/or blepharospasm. The proband developed eye-winking tics in childhood and then developed excessive blinking progressing to blepharospasm by the age of 21 years. His mother presented with Meige's syndrome and spasmodic torticollis at the age of 59 years; his uncle had blinked excessively from his early forties. His eldest son developed an eye-winking tic with facial grimacing at the age of 8 years, and in another son, a self-limiting period of eye-blinking occurred at the age of 4 years. The recovery cycle of the blink reflex was abnormal in all three generations. Three other children with eye-winking tics have a parent or close relative with frequent eye-blinking or blepharospasm. Five patients with adult-onset blepharospasm or Meige's syndrome are also described who had excessive eye-blinking dating back to childhood. It is suggested that eye-winking tics, frequent blinking and blepharospasm may share common pathophysiological mechanisms; the clinical expression may be age-related.

It is usually possible to distinguish between eye-winking tics, frequent eye-blinking and blepharospasm. Eye-winking tics most commonly present in childhood as a rapid, exaggerated, co-ordinated contraction of the orbicularis oculi. They can be voluntarily controlled to some degree and increase in frequency when the child is bored, tired or anxious. There is little functional visual impairment and they usually disappear spontaneously after months or years. Boys are three times more frequently affected than girls and the tic is usually unilateral. ${ }^{1}$ Frequent or excessive eyeblinking is usually secondary to disorders of the ocular surface, tear film, or eyelids; however, it may also occur in otherwise healthy adults as the prodromal sign of essential blepharospasm. It is then usually bilateral, variable in intensity and may be associated with ocular irritation and photophobia.

Blepharospasm consists of repeated, forceful, involuntary sustained contractions of the orbicularis oculi. It most commonly presents in adults and women are more frequently affected than men. Triggers include bright light, reading or watching television and eye movements. It is often associated with oro-mandibular dystonia and is normally intractable, produc-

Address for reprint requests: Dr A J Lees, National Hospital for Nervous Diseases, Queen Square, London WC1N 3BG, UK.

Received 2 August 1988 and in revised form 3 November 1988. Accepted 8 November 1988 ing functional blindness. There may be a family history of blepharospasm or other form of focal dystonia. ${ }^{2}$ Eye-winking tics, excessive blinking and blepharospasm are regarded as distinct pathophysiological entities.

The blink reflexes are abnormal in blepharospasm; the amplitude of the $R 1$ and $R 2$ components is increased, the duration of $R 2$ is prolonged with an abnormal recovery cycle, suggesting hyper-excitability of brain stem neurons. ${ }^{3}$ Blink reflex studies in Gilles de la Tourette's syndrome are also sometimes abnormal suggesting a similar brain stem interneuron hyperexcitability. In this disorder, however, it is possible to correct this by instructing the patient to suppress voluntarily any eye-winking tic before the stimulation takes place ${ }^{4}$ (Smith and Lees, unpublished observation). In both blepharospasm and eye-winking tics, evidence suggests that local eye irritation may be the trigger for the development of abnormal movement.

We report here some evidence to suggest that eyewinking tics, excessive blinking and blepharospasm may be more closely related than current opinion would suggest.

\section{Patients}

Family Cases 1-5: A family with eye-winking tics, excessive blinking and adult-onset focal dystonia (fig)

All affected members of this family were examined by the authors and video films were taken. The proband, a 32 year 


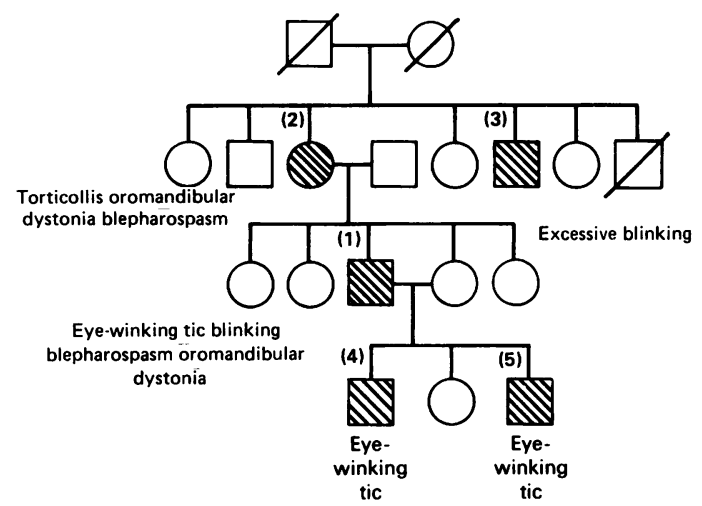

Pedigree of family with focal dystonia and tics.

old man (Case 1), developed an isolated eye-winking tic at the age of 7 , which resolved spontaneously by the age of 11 . He was well until the age of 20 , when he began to blink excessively and become photophobic. At this stage there were no spasms of eye closure and he was able to continue his work as a London Transport driver. The symptoms recovered spontaneously by the age of 23 , but returned again at the age of 28, rapidly worsening to severe blepharospasm. By 29 years of age he was unable to work at all and had become depressed; a number of drug treatments including anticholinergics and benzodiazepines were unhelpful. He has responded well, however, to botulinum toxin A treatment and has been back at work for the last 18 months.

His mother (Case 2) presented at the age of 59 with torsion of the neck, the chin deviating to the left, with no response to anticholinergic drugs. By the age of 61 she had developed frequent eye-blinking, intermittent blepharospasm and oromandibular dystonia. When she attempted to lie flat the cranial dystonia markedly worsened with severe anterocollis. She reported that her younger brother (Case 3) had suffered from excessive eye-blinking in his early forties.

The proband's eldest son (Case 4) developed a winking tic with left-sided facial grimacing at the age of 7 and the younger son (Case 5) has also now developed eye-blinking. The duration and recovery of the R2 components of the blink reflex were abnormal in four family members (table 1). All other investigations were normal including the CT brain scans and wet blood films for acanthocytes.
Table 2 Details of families 2, 3 and 4

\begin{tabular}{|c|c|c|c|c|c|}
\hline Family & Case & $\begin{array}{l}\text { Age (yr) and sex of } \\
\text { onset in proband }\end{array}$ & Condition & Family history & Case \\
\hline 2 & 6 & $4, F$ & eye tic & $\begin{array}{l}\text { Father: (27) exces- } \\
\text { sive blinking }\end{array}$ & -7 \\
\hline 3 & 8 & $5, F$ & eye tic & $\begin{array}{l}\text { Maternal aunt: } \\
\text { (47) blepharo- } \\
\text { spasm (tic as } \\
\text { child) }\end{array}$ & 9 \\
\hline 4 & 10 & $15, \mathrm{M}$ & $\begin{array}{l}\text { excessive } \\
\text { blinking }\end{array}$ & $\begin{array}{l}\text { Father: (39) } \\
\text { blepharospasm } \\
\text { oro-mandibular } \\
\text { dystonia }\end{array}$ & 11 \\
\hline
\end{tabular}

Family Cases 6-11: Children with eye-winking tics or excessive blinking and relatives with excessive blinking or blepharospasm (table 2)

A child (Case 6) with mild generalised developmental delay presented with a predominantly right-sided eye-winking tic at the age of 4 years. Her father (Case 7) is 27 and has been aware of excessive blinking for 5 years; on examination he was photophobic with bouts of excessive blinking elicited by fast eye movements.

An otherwise healthy child (Case 8) developed a left eyewinking tic at the age of 5 that resolved spontaneously 2 years later. During this time he was also noticed to widen his palpebral apertures by pulling faces. His maternal aunt (Case 9) developed blepharospasm at 47 years after having transient eye-winking tic in childhood.

A 15 year old girl (Case 10) developed persistent oculaot discomfort and bilateral excessive blinking following the removal of an eyelash from the upper lacrimal punctum of the left eye. Her father (Case 11) developed excessive blinking spontaneously at the age of 39 ; a year later mild oromandibular dystonia developed.

Cases 12-16: Patients with adult-onset blepharospasm and a previous eye-winking tic or excessive blinking (table 3)

Five patients were seen in this category, three women and two men. The blepharospasm was quite typical in Cases 13-16 and had been preceded by the development of excessive blinking occurring usually around the age of 10 years. This had persisted for between 33 and 57 years (average 43) before it developed into blepharospasm. In one patient there was a family history of oro-mandibular dystonia, in another excessive blinking in a sibling. Case 12 was unusual in that she

Table 1 Blink reflex studies in Family 1

\begin{tabular}{|c|c|c|c|c|c|c|c|c|c|c|}
\hline \multirow{2}{*}{ Case } & \multirow{2}{*}{$\begin{array}{l}\text { Age and sex } \\
\text { of patient }\end{array}$} & \multirow{2}{*}{$\begin{array}{l}\text { Type of movement } \\
\text { disorder }\end{array}$} & \multirow{2}{*}{\multicolumn{2}{|c|}{$R I$}} & \multicolumn{4}{|c|}{ Latencies $(\mathrm{m} / \mathrm{s})$} & & \\
\hline & & & & & \multicolumn{2}{|c|}{ Ipsilateral R2 } & \multicolumn{2}{|c|}{ Contralateral $R 2$} & \multicolumn{2}{|c|}{$\%$ Recovery Cyclet } \\
\hline $\begin{array}{l}4 \\
1 \\
2\end{array}$ & $\begin{array}{l}7 \mathrm{M} \\
32 \mathrm{M}^{*} \\
61 \mathrm{~F}\end{array}$ & $\begin{array}{l}\text { tic } \\
\text { blepharospasm } \\
\text { Meige's syndrome, } \\
\text { torticollis }\end{array}$ & $\begin{array}{l}10 \\
\text { absent } \\
10\end{array}$ & $\begin{array}{l}11 \\
\text { absent } \\
10\end{array}$ & $\begin{array}{l}36 \\
31 \\
38\end{array}$ & $\begin{array}{l}35 \\
32 \\
35\end{array}$ & $\begin{array}{l}38 \\
32 \\
41\end{array}$ & $\begin{array}{l}37 \\
32 \\
35\end{array}$ & $\begin{array}{l}33 \\
59 \\
76\end{array}$ & $\begin{array}{l}42 \\
51 \\
65\end{array}$ \\
\hline
\end{tabular}

*Botulinum toxin $\mathrm{A}$ injection 8 weeks before study.

$\dagger \%$ refer to amplitude of $R 2$ component elicited by test stimulus as a percentage of that elicited by conditioning stimulus. 
Table 3 Details of cases 12-16

\begin{tabular}{|c|c|c|c|c|}
\hline Case & $\begin{array}{l}\text { Preceding } \\
\text { disorder }\end{array}$ & $\begin{array}{l}\text { Age (yr) } \\
\text { and sex }\end{array}$ & $\begin{array}{l}\text { Blepharo- } \\
\text { spasm age }\end{array}$ & Family history \\
\hline 12 & \multirow{5}{*}{$\begin{array}{l}\text { excessive } \\
\text { blinking } \\
\text { excessive } \\
\text { blinking } \\
\text { excessive } \\
\text { blinking } \\
\text { excessive } \\
\text { blinking } \\
\text { tic }\end{array}$} & $9, F$ & 49 & Sister blinks excessively \\
\hline 13 & & $11, \mathrm{~F}$ & 63 & - \\
\hline 14 & & $10, M$ & 43 & \multirow{3}{*}{$\begin{array}{l}\text { Grandmother has oro- } \\
\text { mandibular dystonia } \\
\text { Daughter has eye-wink- } \\
\text { ing tic }\end{array}$} \\
\hline 15 & & $10, M$ & 67 & \\
\hline 16 & & $7, \mathbf{M}$ & 14 & \\
\hline
\end{tabular}

developed a winking tic when aged 7 which has persisted apart from a year of freedom from age 13 to 14. The condition has fluctuated, however, so that in her late 'teens she blinked excessively whereas by her mid-twenties she was housebound by blepharospasm. She is currently only inconvenienced by a largely controllable winking tic. Her eldest daughter developed an eye-winking tic at the age of 5 years.

\section{Discussion}

The fundamental purpose of blinking is the maintenance of the anatomical and optical integrity of the corneal epithelium by the pre-corneal tear film, but normal adults' blink rate (14-17 per minute) is greater than that required for visual purposes, although constant in an individual under fixed conditions. Normal infants and children up to 18 months of age have a low periodic blink rate (2-5 per minute). It is characteristically reduced in patients with Parkinson's disease $^{56}$ and progressive supranuclear palsy ${ }^{7}$ and may be increased in schizophrenia, ${ }^{8}$ Gilles de la Tourette's syndrome ${ }^{9}$ and to a lesser extent depression. ${ }^{10}$ These findings, together with the occurrence of excessive blinking and blepharospasm in disorders which damage the basal ganglia such as Wilson's and Huntington's diseases ${ }^{11}$ suggest that normal periodic blinking is a function of the basal ganglia.

The patients described provide clinical evidence that eye-winking tics, frequent blinking and blepharospasm might be more closely related than has previously been considered. Tolosa and colleagues ${ }^{4}$ drew attention to the similarities between tics and blepharospasm, claiming an increased incidence of tics in the families of patients with Meige's syndrome. Recently a similar occurrence of childhood tic and adult-onset cranial dystonia occurring within the same kindred has been reported. ${ }^{12}$ All the adults (five cases) in the present series showed at different ages more than one of these three abnormalities. In the two cases $(1 \&$ 12) who suffered from all three, the tic occurred in childhood, excessive blinking as a teenager and blepharospasm as an adult; the other four developed excessive blinking around the age of ten, and blepharospasm as adults. In seven out of nine cases another family member had either the same condition (five cases) or a different abnormality of blinking. The age of the affected relative determined the disorder; thus in Case 1, the proband's sons have tics, his mother blepharospasm, the younger uncle excessive blinking or blepharospasm, and Case 7's grandmother had focal dystonia; Case 9's daughter had a tic.

The blink reflex studies carried out in all three affected generations of Family 1 showed an abnormal recovery cycle and one of us (AJL) has found an increased excitability threshold which can be corrected by voluntary suppression in a proportion of patients with Gilles de la Tourette's syndrome. It seems probable that the underlying basal ganglia dysfunction in Case 1 is genetically determined and there is evidence that both tics and blepharospasm may be familial. ${ }^{12} 13$ The clinical expression of the underlying movement control varies and may reflect age-related changes in the maturational development of control of blinking. Thus winking tics develop at an age when the normal adult rate of blinking is being established. Excessive blinking seems to develop around the age of ten, which may be another blink control maturational landmark, whereas blepharospasm develops in adults. The precipitant at each age is unclear, but recent evidence points to the possibility that local trauma may be important. Ocular surfaces, tear film or eyelid abnormalities, even when minor, normally increase blinking; in susceptible individuals this may unbalance the control mechanism and produce various degrees of involuntary perpetuation. Many children with eyewinking tics complain of irritation of the affected eye and since minor corneal and lid trauma (such as seen in Case 10) is common, this may be a precipitant in these cases also. ${ }^{14}$ is Although it is impossible to exclude a chance association between two common movement disorders we would like to suggest tentatively that eyewinking tics, excessive blinking and blepharospasm may be age-related manifestations of the same fundamental abnormality.

\section{References}

1 Lees AJ. Tics and Related Disorders. Edinburgh: Churchill Livingstone, 1985:14.

2 Jankovic J, Ford J. Blepharospasm and oro-facialcervical dystonia: clinical and pharmacological findings in 100 patients. Ann Neurol 1983;13:407-11.

3 Berardelli A, Rothwell JC, Day BC, Marsden CD. Pathophysiology of blepharospasm and oromandibular dystonia. Brain 1985;108:593-608.

4 Tolosa E, Montserrat L, Bayes A. Reduction of brain stem interneuron excitability during voluntary tic inhibition in Tourette's syndrome. Neurology 1986;36(suppl): 118-9.

5 Carney LG, Hill RM. The nature of blinking patterns. 
Acta Ophthalmol 1982;60:427-33.

6 Karson CN. Spontaneous eye-blink rates and dopaminergic systems. Brain 1983;106:643-53.

7 Jackson JA, Jankovic J, Ford J. Progressive supranuclear palsy: clinical features and response to treatment in 16 patients. Ann Neurol 1983;13:273-8.

8 Stevens JR. Disturbances of ocular movements and blinking in schizophrenia. $J$ Neurol Neurosurg Psychiatry 1978;41:1024-30.

9 Lees AJ, Robertson M, Trimble MR, Murray NMF. A clinical study of Gilles de la Tourette's syndrome in the United Kingdom. J Neurol Neurosurg Psychiatry 1984:47:1-8.

10 Mackintosh JN, Kumar R, Kifamara T. Blink rate in psychiatric illness. Br J Psychiatry 1983;143:55-7.

11 Bruyn GW. Huntington's chorea. In: Vinker PT, Bruyn
GW, eds. Handbook of Clinical Neurology. Vol 6. Diseases of the Basal Ganglia. Amsterdam: NVKHolland Publishing Co, 1968:298-378.

12 Jankovic J, Nutt JG. Blepharospasm and cranial-cervical dystonia (Meige's syndrome): familial occurrence. In: Jankovic J, Tolosa E, eds. Adv Neurol Vol 149. Facial Dyskinesias. New York: Raven Press, 1988:117:24.

13 Nutt JG, Hammerstadt JP. Blepharospasm and oromandibular dystonia (Meige syndrome) in sisters. Ann Neurol 1981;9:189-91.

14 Schott GD. Induction of involuntary movements by peripheral trauma: an analogy with causalgia. Lancet 1986;1:712-5.

15 Brin MF, Fahn S, Bressman SB, Birne RE. Dystonia precipitated by peripheral trauma. Neurology 1980;36(suppl 1):119. 